\title{
APPLICATION OF THE CANTOL ROUDHOH METHOD TO IMPROVE STUDENT'S READING ABILITY IN RA SITI FATIMAH
}

\section{Muhammad Fahmi}

Green Publisher

Email: fahmimuhammad103@gmail.com

Keywords Abstract The application of learning to read cantol Cantol Roudhoh, roudhoh is one of the learning techniques that can Learning, improve children's language skills. This technique is very

Learning Method Article Info

January, $2^{\text {nd }} 2021$

Revised:

January, $13^{\text {th }} 2021$

Approved:

January, $14^{\text {th }} 2021$ suitable for early childhood learning. The results of research conducted at RA Siti Fatimah, Harjamukti Village, Cirebon City, showed that the objective conditions of language learning were studied from the teacher's perspective, positive responses of children, teaching and learning processes, and supporting facilities, using the cantol roudhoh method which was applied in developing aspects of language, and skills children's language that can develop as expected. The implementation of this raudhoh hook method in its application process at RA Siti Fatimah is to practice in class $A$, which is to introduce hooks from her friends in clothes to her friends, Zahra, after reaching the target of her friends, Zahra continues on package B, which is entering the introduction of vocal groups (a, i, u, e, o), after that they enter the ng (cat) group, then enter the Koran group (nga, ngi, ngu, nge, ngo) and mosquitoes (nya, nyi, nyu, nye, nyo ). The last stage is the introduction of hooks with consonants. 


\section{Muhammad Fahmi}

\section{Introduction}

Education is a conscious and planned effort to create a learning atmosphere and learning process so that students actively develop their potential to have religious spiritual strength, self-control, personality, intelligence, noble character, and skills needed by themselves, society, nation and state (Undang-Undang, 2003).

Education, however, is the most urgent thing in human life. Education from the past until now is still something that must be prioritized over others. As mentioned in Chapter II, article 1: "National education is based on Pancasila and the 1945 Constitution of the Republic of Indonesia". Conceptually, the basis of this national education contains values that are unquestionably reliable, very ideal and noble, and by consensus the entire Indonesian nation has accepted it. Because the essence of the two bases is philosophically part of Islamic philosophy, meaning that all the contents and meanings do not conflict with Islamic teachings, and are even reflected in Islamic teachings.

Therefore, the two basics must be translated and interpreted in an Islamic way, with a pattern of internalizing Islamic values into the entire content and meaning of the two bases (Masdudi, 2014). Thus, every state administration, including the implementation of educational units, will be filled with values that are increasingly synonymous with Islamic teachings. Meanwhile, the essence of the function of national education is stipulated in Article 2 of the National Education System Law, namely: "Developing capabilities and shaping the character and civilization of a dignified nation in the context of the intellectual life of the nation". This sentence is simple, but has a deep and broad meaning (Nurjaman, 2017). 
Creative and innovative learning should be carried out by teachers in an effort to produce creative students (Supriadi, 2018). The level of success of teachers in teaching is seen from the success of their students so that it is said that a great teacher is a teacher who can inspire students. The quality of learning is seen from the activities of students when studying and the creativity that can be done by students after participating in learning (Sani, 2013).

There are three important aspects that are interrelated with each other in the learning process (Bistari, 2017). The three aspects are the subject matter being taught, the process of learning the material, and the results of the learning process (Sinambela, 2017). So far, the focus and attention of educators has been more devoted to just busying themselves with the delivery of learning materials and learning outcomes. Some of their time is consumed just to prepare lesson plans and other learning administrative tools. Meanwhile, more efforts by an educator to design a good learning process so that learning objectives can be achieved are actually neglected (Hidayat, Sa'diyah, \& Lisnawati, 2020).

Learning to read requires teachers to be creative because they have to motivate children to learn (Oktiani, 2017). Reading ability is not only closely related to the maturity of eye motor movements but also the stage of cognitive development (Ariyati, 2014; Aryaningsih, Fathoni, \& Harini, 2018) Early childhood education is not required to require children to be able to read fluently, at least at that age they are introduced to early reading, at least children know letters while understanding the forms of letters, making it easier for children to learn to read fluently. The way to make it easier for children to learn to read is to apply learning methods that suit the child's needs. Children's education requires an interesting method of 


\section{Muhammad Fahmi}

learning to read. The use of media or tools is useful to increase children's interest in learning, this will provide variety in children's learning so that children do not feel bored quickly and do not feel burdened by learning to read.

Research on education has been done by many previous researchers. One of them is a study that examines the relevance of educators according to KH. Hasyim Asy'ari with the 2003 National Education System Law which states that the competence of educators must be in accordance with the mandate of the law and this is justified by $\mathrm{KH}$. Hasyim Ashari (SOLIKHAH, 2021). Other research on laws has also been studied in the paradigm of Islamic education from a legal perspective (Muhammad Ghofar, 2018) related to the cantol raudhoh method has also been studied by examining the effect of the cantol roudhoh method in measuring early childhood reading skills. (Budi Utami, 2013) the use of the cantoul roudhoh method was also studied to determine students' reading beginnings (Tri, 2019) and an analysis of the effects of the cantol roudhoh method was also discussed to determine students' literacy skills in early childhood (Lestari, 2018).

In education, the teacher becomes one of the important elements that cannot be left behind in guiding students, teacher guidance is very helpful in increasing children's interest in being able to listening and reading. The implication is that teachers must prepare an interesting and fun learning environment. Interesting learning is expected to foster interest in reading and learning, children's curiosity will be seen from their enthusiasm and concentration when children listen to the material given by the teacher.

The application of learning to read with the cantol roudhoh method is one of the learning techniques that can improve children's language skills. Thus, the application of the cantol roudhoh reading technique is suitable for 
Volume 2 Number 2, January, 2021 p-ISSN: 2777-0915 | e-ISSN 2797-6068

early childhood. The results of observations made at RA Siti Fatimah, Harjamukti Village, Cirebon City, the objective conditions of language learning were studied from the teacher's perspective, the positive response of children, the teaching and learning process, and supporting facilities, especially in the development of the language aspect, which applied the cantol roudhoh reading method, language skills children develop as expected.

The cantol roudhoh reading method is a learning method that develops learning to recognize syllables with the hook system which is conveyed through storytelling, singing, and playing, using props. Storytelling is done by reading story books based on visual, auditory, and kinesthetic modalities. In singing, children are taught to sing through CD/DVD songs using the roudhoh hook method. Playing is conveyed through guessing words using syllable hook letter cards, hook magnet boards, loop hooks, and reading cards. With these methods and media, children will remember and memorize various symbols of letters or syllables.

\section{Research Method}

The research method used in this study is a qualitative method with an analytical descriptive approach where this research method is based on post positivism philosophy, the condition of the natural object, where the researcher is the key instrument, the data collection technique is done by triangulation (combined). This study aims to obtain data on the application of the cantol roudhoh reading method in improving children's reading skills. In essence, this research will be studied to obtain data, understand, 


\section{Muhammad Fahmi}

and describe the application of reading cantol roudhoh in improving children's reading skills in RA Siti Fatimah, Harjamukti Village, Cirebon City.

\section{Result and Discussion}

\section{A. Result}

In the initial conditions of low learning outcomes, the concentration of students in participating in cantol roudhoh learning is still lacking, students do not dare to ask questions, have difficulty practicing questions, do not dare to express opinions and are less active. This is used as a benchmark to increase student concentration so that better learning processes and results are obtained, especially in improving learning outcomes of cantol roudhoh.

Based on the results of the interviews, it can be concluded that the cantol roudhoh method at RA Siti Fatimah has a positive impact on children, and provides a stimulant for children to be more active in learning in class. Because there is no coercion or punishment, it is a game that encourages them to learn, and teachers can streamline teaching and learning activities, this method teaches simple reading by using colored pictures.

The application of the cantol roudhoh method in learning at RA Siti Fatimah received a positive response both for teachers who teach and from students who are taught because this method is quite simple and easy to practice in early childhood learning so that the teacher's role is not only as an educator but also as a facilitator in learning which produces fun and joy in children learning to read in the RA Siti Fatimah environment, Cirebon City. 


\section{B. Discussion}

\section{1) Understanding the Roudhoh Cantol Method}

According to (Riana Simbolon Kasiyati, 2013) the cantol raudhoh method is one of the memorization techniques developed in quantum learning. In its application, this method is associated (combined) in the equation of sound and visual form. It is one of the effective memorization methods for remembering lists. Through this method children can easily memorize every syllable that is in each hook and is supported by showing pictures that match the nouns that have been modified based on the child's problems.

The raudhoh hook method is one method that introduces letters and syllables consisting of a combination of letters assisted by hooks in the form of pictures using reading cards to make it easier for children to remember all letters and syllables. Setyono explains that based on 2 principles, namely the use of cantol raudhoh, namely maximizing the ability of a child's brain to absorb information and the principle of a fast memorization system, this is the basis for the development of the cantol raudhoh reading method with a system of singing, playing and telling stories using props. In its application, the singing system in this method uses a song with 21 syllable hooks ba-bi-bu-be-bo attached to the word clothes with the lyrics in the song containing the syllables ba, bi, bu, be, bo which are repeated until the syllables are repeated za-zi-zu-ze-zo which is attached with the word zahra with the lyrics in the song contains the repeated syllables za, zi, zu, ze, zo.

The system plays through the color clock game by reading word cards consisting of picture cards spiked with syllable variations. The storytelling system tells the story of Zahra's adventures on the island of reading by 


\section{Muhammad Fahmi}

introducing all the variations of syllables and the words they say. This example is one of the most effective memorization methods for remembering. In teaching reading, these techniques are needed to make it easier for children to remember letter symbols. An effective reading introduction is to introduce all the basic syllable sounds that form words in Indonesian.

The Raudhoh cantol reading method was developed based on the principles or rules agreed upon by the experts. Both education experts and experts in the development of children's potential. Based on these theories, the Raudhoh Reading Cantol Method was developed into a scientific method and very relevant to the development of child psychology (Sartika, Arifudin, \& Amini, 2018).

\section{2) The principle of the Raudhoh cantol reading method}

The principle of the cantol raudhoh reading method is to maximize the brain's ability to absorb information, and the system to memorize quickly. These two principles are the basis for the development of the Raudhoh Cantol Reading Method with a system of singing, playing and telling stories using props. In the cantol raudhoh method, there are four available media, namely Song Animation VCD, Guidance VCD, Cantol Circle, and Reading Card. The tool used in this research is the Reading Card.

\section{3) Steps of the Raudhoh Cantol Method}

The following are the steps for applying the cantol raudhoh method as follows: First, in the core activities, children carry out reading activities according to the procedures for applying the cantol raudhoh method, which is directed to first master their memory walkway in the rhythm of the sound of the same group, namely $a, i, u, e, o$. Second, after that the child will know the sound of the group, it is enough if he knows the initial 
sound of the syllable group, namely ba, ca, da, and so on. Third, to help the child as a support in the pattern of thinking, the initial tribe is given hooks in the form of the names of objects whose initial syllable sound is the same as the initial syllable sound of each group.

For example, the first group of hooks is "clothes", the second group is "chilli", and the third group is "dice" and so on. The names of the objects used as hooks are sought to be known by the children. Cantolan is applied in the form of cards that are used as props. For example, group one with a picture of a dress card, group two with a picture of a chili pepper, and so on. Fourth, then on the hook of group one, namely clothes, the child is emphasized on the initial syllable, namely "ba". Likewise for "ca" hooks and so on. If the child has understood the memory walkway of each group, then automatically each group of syllables will recognize each syllable through this hook. Fifth, then for the writing ability hook, the child will write in a checkered book and the child will see the previous reading card.

\section{4) Advantages of the Raudhoh Cantol Method}

The cantol raudhoh method is one suitable method to make it easier for children to remember letter symbols, in introducing syllables, the sound of each group is the same, namely a, i, u, e, o. If the child is able to catch the footbridge, this memory is the same as for other syllable groups. Children can already guess the syllables of other groups that has not been introduced to him, and when the child knows from a to $z$ the child can correctly guess the sound of the syllable.

This makes the child will quickly recognize all the sounds of the syllables. But for children who do not know the letters need a frame of mind that can help children to remember them easily. This is where the advantage of the 
raudhoh hook method, where the hooks are very effective in helping the child's frame of mind. In addition, the advantages of this cantol method are that children can read more quickly and easily in an average of 20-32 hours, foster a high interest in reading, conveyed by playing, singing, and telling stories.

\section{5) Relationship between Raudhoh Cantol Method and Reading Ability}

The Cantol Raudhoh method is a way for teachers to introduce reading to children using a tool that can convey the learning process will be more interesting and fun. Meanwhile, reading activities often make children bored if they are only used by using less interesting media. Therefore, by using the cantol raudhoh method children will be more active in reading activities, will increase children's learning motivation, be consistent with child-centered learning, guide to better learning and accelerate understanding and help children improve reading skills in early childhood.

\section{Conclussion}

Based on the results of the research and discussion that has been described regarding the application of the cantol roudhoh method in the development of beginning reading at RA Siti Fatimah Cirebon City, it can be concluded that the application of the cantol roudhoh method in developing early reading skills at RA Siti Fatimah Cirebon City is in accordance with the specified standards. The process of using the roudhoh hook method for package $A$ is to introduce hooks from her friends in clothes to her friends, after reaching the target of her friends, Zahra goes on to package $B$, which is to enter the introduction of vocal groups $(a, i, u, e, o)$. ), after that they enter the ng (cat) group, then enter the Koran (nga, ngi, ngu, nge, ngo) and mosquito (nya, nyi, nyu, nye, nyo) groups. The last stage is the introduction of hooks with consonants. 
The use of the cantol roudoh method which is applied in developing early reading skills at RA Siti Fatimah, Cirebon City has been carried out well, seen from students being able to read, understanding in distinguishing syllable sounds properly and correctly.

\section{References}

Ariyati, Tatik. (2014). Peningkatan Kemampuan Membaca Permulaan Melalui Penggunaan Media Gambar. Jurnal Pendidikan Usia Dini, 8(1), 47-54.

Aryaningsih, Yuni Yuni, Fathoni, Azis, \& Harini, Cicik. (2018). Pengaruh Return On Asset (Roa), Return On Equity (Roe) Dan Earning Per Share (Eps) Terhadap Return Saham Pada Perusaahn Consumer Good (Food And Beverages) Yang Terdaftar Di Bursa Efek Indonesia (Bei) Periode 2013-2016. Journal Of Management, 4(4).

Bistari, Bistari. (2017). Konsep Dan Indikator Pembelajaran Efektif. Jurnal Kajian Pembelajaran Dan Keilmuan, (2), 13-20.

Budi Utami, Rizky. (2013). Pengaruh Metode Cantol Roudhoh Terhadap Kemampuan Membaca Anak Usia Dini Kelompok B Di Tk Cendekia Mulia Surabaya. Paud Teratai, 2(2).

Hidayat, Ariep, Sa'diyah, Maemunah, \& Lisnawati, Santi. (2020). Metode Pembelajaran Aktif Dan Kreatif Pada Madrasah Diniyah Takmiliyah Di Kota Bogor. Edukasi Is/ami: Jurnal Pendidikan Islam, $9(1), 71-86$.

Lestari, Dea Rika. (2018). Analisis Efek Metode Cantol Roudhoh Terhadap Kemampuan Literasi Dini Pada Anak: Studi Kasus Terhadap Anak Kelas Dua Sekolah Dasar Yang Pernah Mengikuti Metode Cantol Roudhoh Di Kecamatan Cicalengka-Kabupaten Bandung. Universitas Pendidikan Indonesia.

Masdudi, M. (2014). Landasan Pendidikan Islam Kajian Konsep Pembelajaran. Cu. Elsi Pro. 
Muhammad Ghofar, Amrullah. (2018). Strategi Pembelajaran Al-Qur'an Dengan Metode Yanbu'a Dalam Meningkatkan Kualitas Pelafalan Huruf (Studi Kasus Di Mts Darul Huda Mayak Tonatan Ponorogo). lain Ponorogo.

Nurjaman, Ujang. (2017). Implikasi Uu Sisdiknas Terhadap Pendidikan Islam. Jurnal Pendidikan Uniga, $7(1), 52-60$.

Oktiani, Ifni. (2017). Kreativitas Guru Dalam Meningkatkan Motivasi Belajar Peserta Didik. Jurnal Kependidikan, 5(2), 216-232.

Riana Simbolon Kasiyati, Irdamurni. (2013). Fektifita Meetode Cantol Roudhoh Untuk Meningkatkan Kemampuan Membaca Permulaan Bagianak Tunagrahita Ringan. Jurnal Penelitian Pendidikan Khusus, 2(3).

Sani, Ridwan Abdullah. (2013). Inovasi Pembelajaran. Jakarta: Bumi Aksara.

Sartika, Ika, Arifudin, Yadi Fahmi, \& Amini, Fadlilah Aisyah. (2018). Meningkatkan Kemampuan Membaca Anak Melalui Metode Cantol Raudhoh (Penelitian Di Raudhatul Athfal Waladun Solihun Kecamatan Imbanagara Kabupaten Ciamis). Tarbiyat Al-Aulad: Jurnal Pendidikan Islam Anak Usia Dini, 2(2).

Sinambela, Pardomuan N. J. M. (2017). Kurikulum 2013 Dan Implementasinya Dalam Pembelajaran. Generasi Kampus, 6(2).

Solikhah, Tridiganita Intan. (2021). Dilema Pembelajaran Daring Selama Masa Pandemi Covid-19. Kampus Merdeka Seri 5: Transformasi Media Pengajaran Kampus Merdeka Di Era Kenormalan Baru, 75.

Supriadi, Dudun. (2018). Implementasi Manajemen Inovasi Dan Kreatifitas Guru Dalam Meningkatkan Mutu Pembelajaran. Indonesian Journal Of Education Management \& Administration Review, (2), 125-132. 
Volume 2 Number 2, January, 2021 p-ISSN: 2777-0915 | e-ISSN 2797-6068

Tri, Cahyaningrum. (2019). Penggunaan Metode Cantol Roudhoh Dalam Pengembangan Kemampuan Membaca Permulaan Di Tk Nakita Insan Mulia Purwokerto. lain Purwokerto.

Undang-Undang. Tentang Sistem Pendidikan Nasional. , (2003).

\author{
$\star \star \star$ \\ Copyright holder : \\ Muhammad Fahmi (2021) \\ First publication right : \\ Devotion - Journal of Community Service \\ This article is licensed under:

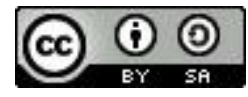

